\title{
Hemisphere differences in response rates to visual stimuli in children
}

\author{
M. A. JEEVES \\ University of St. Andrews, St. Andrews, Fife, Scotland
}

A further series of experiments designed to study response rates to unstructured visual stimuli, but with children instead of adults as Ss, confirmed an earlier finding with adults that responses are faster when the input goes initially to the right hemisphere, as compared with the left. The hemisphere difference, however, while clear-cut in the case of right-handed children, failed to reach significance for the left-handers. Likewise, the response rates for four possible response pathways showed the same consistent pattern reported in the earlier study for the right-handed children but not for the left-handers. None of the hemisphere differences which emerged were as large for the children as for the adults. The results are discussed in the context of other findings on the development of cerebral asymmetry of function.

In an earlier communication (Jeeves \& Dixon, 1970), we reported that visual stimulation going initially to the right hemisphere is responded to faster than stimulation going initially to the left hemisphere. In that study, the experimental Ss were young adults aged 20-22 years. Although the three subexperiments upon which that report was based demonstrated the consistency and robustness of the phenomenon, it was nevertheless felt desirable to replicate the experiment yet again, but this time with Ss drawn from a younger age group. This was done for two reasons: first, that by replicating the experiment in a different setting, i.e., in a school instead of the laboratory, we could further eliminate the likelihood that our earlier finding was the result of some undetected experimental artifact; second, that by studying children, we might throw light on another aspect of the development of cerebral asymmetry of functioning.

\section{METHOD}

The apparatus and procedure for this experiment were the same as those employed and described in detail in an earlier report (Jeeves \& Dixon, 1970). However, instead of being set up in the psychological laboratory, the experiment was carried out at a local school. The Ss of the experiment were 20 boys whose ages ranged from 9 years 6 months to 11 years 5 months. Ten of the boys described themselves as right-handed and 10 as left-handed.

In different experiments, light stimuli fell upon either the nasal or the temporal parts of the retinae. For the nasal condition, bright point sources of light, well above threshold, at a distance of $171 / 2 \mathrm{~cm}$ and at an angle of $70 \mathrm{deg}$ to the midline, flashed on for durations of $2 \mathrm{msec}$. Ss were told that when a warning buzzer sounded, they should press down two Morse keys and ensure that they were fixating a central point on a gray screen $2 \mathrm{~m}$ to their front. Immediately when a stimulus appeared, they were to release both keys as quickly as possible. The period between the sounding of the buzzer and the appearance of the stimulus took 1 of 10 possible values: $.07, .08, .09, .10$, $.11, .12, .13, .14, .15$, and $.16 \mathrm{sec}$; it was varied randomly, but with equal numbers of all possible foreperiods on each day. Ss made 60 responses under each of two different conditions at a sitting, i.e., a total of 120 , and came back for 5 successive days of testing. For the temporal stimulation conditions, Ss wore a black plastic spectacle frame with lights embedded within the frame so that only the temporal part of the retina was stimulated when they flashed on. The same stimulus duration and variation in foreperiods were used as in the nasal condition. Thus, each $S$ made a total of 300 responses under each of the two conditions, nasal and temporal.

In all experiments, Ss were comfortably seated with their heads restrained in a harness. Response times were measured on two electronic timers accurate to $10^{-6} \mathrm{sec}$. Measurements were taken to the nearest millisecond.

\section{RESULTS}

Table 1 presents a summary of the data so as to compare response times by right-handed and left-handed Ss under conditions of nasal and temporal retina stimulation, depending upon which cerebral hemisphere the sensory input went to initially. For comparison purposes, the relevant data from the earlier experiment with adult $\mathrm{Ss}$ is given in Table 2. It is at once apparent from comparing the right-hand columns of the two tables that the consistency of the right-hemisphere superiority is not present in the childrens' data to the same extent as with the adults. Thus, while the right-handed children showed the same right-hemisphere superiority as had been observed with the adults, the left-handed children did not show such a consistent right-hemisphere superiority. In fact, only $5 / 10$ and $6 / 10$ of the left-handed children showed such superiority for the nasal and temporal stimulation conditions, respectively.

The differences between the response times of the right- and left-hemisphere stimulation conditions were analyzed separately for right- and left-handed children, using a Wilcoxon matched-pairs signed-rank test. This gave $T$ right-handers (nasal and temporal conditions combined) $=32$ $(\mathrm{p}<.01)$ and $\mathrm{T}$ left-handers (nasal and temporal conditions combined) $=101$ (n.s.).

A comparison of Tables 1 and 2 indicates, as would be expected, that adult $\mathrm{Ss}$ respond faster than children. The magnitude of this difference is of the order of $50 \mathrm{msec}$.

\section{DISCUSSION}

Since the apparent discrepancy between the results of the earlier study, in which young adults 20-22

\begin{tabular}{|c|c|c|c|c|c|c|}
\hline \multirow[b]{2}{*}{$\begin{array}{c}\text { Ss } \\
\text { Children }\end{array}$} & \multirow[b]{2}{*}{$\begin{array}{c}\text { Number } \\
\text { of Ss }\end{array}$} & \multirow{2}{*}{$\begin{array}{c}\text { Part of } \\
\text { Retina } \\
\text { Receiving } \\
\text { Stimulation }\end{array}$} & \multicolumn{2}{|c|}{$\begin{array}{l}\text { Mean RT for } \\
\text { Stimulation } \\
\text { Arriving in the }\end{array}$} & \multirow{2}{*}{$\begin{array}{l}\text { Difference } \\
\text { in RT to } \\
\text { Stimulation } \\
\text { Arriving in } \\
\text { Different } \\
\text { Hemispheres } \\
\text { (LH-RH) }\end{array}$} & \multirow{2}{*}{$\begin{array}{c}\text { Number of Ss } \\
\text { Showing Left } \\
\text { Hemisphere } \\
\text { Slower Than } \\
\text { Right }\end{array}$} \\
\hline & & & $\begin{array}{c}\text { Right } \\
\text { Hemisphere }\end{array}$ & $\begin{array}{c}\text { Left } \\
\text { Hemisphere }\end{array}$ & & \\
\hline $\begin{array}{l}\text { Right-Handed } \\
\text { Left-Handed }\end{array}$ & $\begin{array}{l}10 \\
10\end{array}$ & $\begin{array}{l}\text { Nasal } \\
\text { Nasal }\end{array}$ & $\begin{array}{l}312.27 \\
305.85\end{array}$ & $\begin{array}{l}318.30 \\
309.59\end{array}$ & $\begin{array}{l}+6.03 \\
+3.74\end{array}$ & $\begin{array}{l}8 \\
5\end{array}$ \\
\hline $\begin{array}{l}\text { Right-Handed } \\
\text { Left-Handed }\end{array}$ & $\begin{array}{l}10 \\
10\end{array}$ & $\begin{array}{l}\text { Temporal } \\
\text { Temporal }\end{array}$ & $\begin{array}{l}301.05 \\
299.38\end{array}$ & $\begin{array}{l}306.23 \\
295.64\end{array}$ & $\begin{array}{l}+5.18 \\
-3.74\end{array}$ & $\begin{array}{l}8 \\
4\end{array}$ \\
\hline
\end{tabular}




\begin{tabular}{|c|c|c|c|c|c|c|}
\hline \multirow[b]{2}{*}{$\begin{array}{l}\text { Ss } \\
\text { Children }\end{array}$} & \multirow[b]{2}{*}{$\begin{array}{l}\text { Number } \\
\text { of Ss }\end{array}$} & \multirow{2}{*}{$\begin{array}{c}\text { Part of } \\
\text { Retina } \\
\text { Receiving } \\
\text { Stimulation }\end{array}$} & \multicolumn{2}{|c|}{$\begin{array}{l}\text { Mean RT for } \\
\text { Stimulation } \\
\text { Arriving in the }\end{array}$} & \multirow{2}{*}{$\begin{array}{l}\text { Difference } \\
\text { in RT to } \\
\text { Stimulation } \\
\text { Arriving in } \\
\text { Different } \\
\text { Hemispheres } \\
\text { (LH-RH) }\end{array}$} & \multirow{2}{*}{$\begin{array}{c}\text { Number of Ss } \\
\text { Showing Left } \\
\text { Hemisphere } \\
\text { Slower Than } \\
\text { Right }\end{array}$} \\
\hline & & & $\begin{array}{c}\text { Right } \\
\text { Hemisphere }\end{array}$ & $\begin{array}{c}\text { Left } \\
\text { Hemisphere }\end{array}$ & & \\
\hline $\begin{array}{l}\text { Right-Handed } \\
\text { Left-Handed }\end{array}$ & $\begin{array}{l}10 \\
10\end{array}$ & $\begin{array}{l}\text { Nasal } \\
\text { Nasal }\end{array}$ & $\begin{array}{l}268.35 \\
240.41\end{array}$ & $\begin{array}{l}273.34 \\
248.95\end{array}$ & $\begin{array}{l}+4.99 \\
+8.54\end{array}$ & $\begin{array}{l}7 \\
8\end{array}$ \\
\hline $\begin{array}{l}\text { Right-Handed } \\
\text { Left-Handed }\end{array}$ & $\begin{array}{l}10 \\
10\end{array}$ & $\begin{array}{l}\text { Temporal } \\
\text { Temporal }\end{array}$ & $\begin{array}{l}252.94 \\
231.52\end{array}$ & $\begin{array}{l}260.03 \\
236.25\end{array}$ & $\begin{array}{l}+7.09 \\
+4.73\end{array}$ & $\begin{array}{l}9 \\
8\end{array}$ \\
\hline
\end{tabular}

Table 3

Results of a Questionnaire Measure of Handedness

\begin{tabular}{|c|c|c|c|c|c|c|}
\hline & \multicolumn{6}{|c|}{ Experimental Groups } \\
\hline & \multicolumn{3}{|c|}{ Right-Handed } & \multicolumn{3}{|c|}{ Left-Handed } \\
\hline & Mean & Range & $\mathrm{N}$ & Mean & Range & $\mathbf{N}$ \\
\hline Children & 18.2 & $14-24$ & 10 & 58.6 & 44-70 & 10 \\
\hline Adults & 22.2 & $16-38^{*}$ & 10 & 59.7 & $38-68 \div$ & 10 \\
\hline
\end{tabular}

*The range of scores for $9 / 10$ of the right-handed adults was $16-23$ and the tenth $S$ had a score of 38 .

The range of scores for $9 / 10$ of the left-handed adults was 47.68 and the tenth $S$ had a score of 38 .

years old took part, and the present one, with children $10-11$ years old occurs only with the left-handed children, one immediately questions whether the rough method of selection of right- and left-handers may have been responsible for this. In the adults' experiment, Ss simply reported whether they considered themselves consistently right-handed or left-handed and they were assigned to experimental groups on that basis alone. Likewise, in the case of the children, the allocation to right- and left-handed groups was made on the children's own profession of handedness. If some of the children had been inaccurate in their assessment or reporting of their own handedness, it could have resulted in the group of supposed left-handers in fact being a mixed group composed of right-handers, left-handers, and those who were not sure. One way of checking on this was to administer a questionnaire index of handedness The one selected was that devised by Crovitz \& Zener (1962) and extensively used at Duke University. It scores 14 items on a 5-point scale, giving a highest possible right-handed score of 14 and a highest left-handed score of 70 . Table 3 presents the results of this questionnaire for both adults and children. Clearly, on this evidence, the children cannot be differentiated from the adults on the grounds of differences in reliability of categorization of handedness in the two cases.

The weight of evidence concerning the development of cerebral dominance (Kimura, 1967; Annett, 1970) suggests that, in general, left-hemisphere dominance for speech is well established by Age 8 in both boys and girls. There is also some evidence to suggest that boys may lag behind girls in the development of such dominance (Kimura, 1967;
Taylor, 1962). Kimura (1967) has pointed out that this finding has a parallel in Ghent's (1961) demonstration of a lag in the development of somesthetic asymmetry in boys. However, since the stimuli used in this experiment have neither verbal nor spatial qualities, it is a dubious exercise to look for an explanation of the results of this experiment from studies concerned with the development of dominance for speech and verbal material. There is, therefore, at present no satisfactory explanation of the results of this experiment, and it would be helpful to repeat it with equal numbers of boys and girls.

In our earlier communication, we also noted the consistent ordering from fastest to slowest of the four possible response pathways. We found that for all combinations of conditions studied (right-handers, left-handers, two-handed responding, single-handed responding), the order from fastest to slowest was (1) right-hemisphere receiving, right-hand responding, (2) right-hemisphere receiving, le $\mathrm{ft}-\mathrm{h}$ and responding, (3) left-hemisphere receiving, right-hand responding, and (4) left-hemisphere receiving, left-hand responding. When the results of the present experiment with children are analyzed in this way (Table 4), we find that the right-handed children produce the same rank ordering of pathways as the adults under conditions of both

Table 4

\begin{tabular}{|c|c|c|c|c|c|}
\hline Ss & $\begin{array}{c}\text { Part of } \\
\text { Retina } \\
\text { Receiving } \\
\text { Stimulation }\end{array}$ & $\begin{array}{c}\text { Hand } \\
\text { Response } \\
\text { Being } \\
\text { Measured }\end{array}$ & $\begin{array}{c}\text { Short Pathway } \\
\text { (Intrahemispheric) }\end{array}$ & $\begin{array}{c}\text { Long Pathway } \\
\text { (Interhemispheric) }\end{array}$ & $\begin{array}{c}\text { Comparison } \\
\text { With Previous } \\
\text { Adult Data }\end{array}$ \\
\hline Right-Handed & Nasal & $\begin{array}{l}\mathrm{R} \\
\mathrm{L}\end{array}$ & $\begin{array}{ll}315.76 & (3) \\
313.38 & (2)\end{array}$ & $\begin{array}{l}311.16(1) \\
320.83(4)\end{array}$ & Same as Adults \\
\hline Left-Handed & Nasal & $\begin{array}{l}\mathbf{R} \\
\mathbf{L}\end{array}$ & $\begin{array}{l}308.77 \text { (3) } \\
305.37 \text { (1) }\end{array}$ & $\begin{array}{l}306.33(2) \\
310.40(4)\end{array}$ & $\begin{array}{l}\text { (1) and (2) Reversed } \\
\text { cf. With Adults }\end{array}$ \\
\hline Right-Handed & Temporal & $\begin{array}{l}\mathbf{R} \\
\mathbf{L}\end{array}$ & $\begin{array}{l}304.97(3) \\
301.09(2)\end{array}$ & $\begin{array}{l}301.01 \text { (1) } \\
307.50 \text { (4) }\end{array}$ & Same as Adults \\
\hline Left-Handed & Temporal & $\begin{array}{l}\mathrm{R} \\
\mathbf{L}\end{array}$ & $\begin{array}{l}292.58(1) \\
301.66(4)\end{array}$ & $\begin{array}{l}297.09(2) \\
298.72(3)\end{array}$ & $\begin{array}{l}\text { Different Order } \\
\text { from Adults }\end{array}$ \\
\hline
\end{tabular}

Note-Rank order from fastest (1) to slowest (4) shown in parentheses 
nasal and temporal stimulation. The left-handers under the nasal stimulation condition show Pathways 1 and 2 in reversed order but Pathways 3 and 4 the same. The left-handers under the temporal stimulation condition produce a difference order in all respects from the comparable group of adults. Once again then, we find the right-handers among the adults and children performing in a like manner but the left-handers among the children performing differently from their right-handed peers and from all the adults, right-handed and left-handed, tested so far.

\section{REFERENCES}

ANNETT, $M$ The growth of manual preference and speed. British Journal of Psychology, 1970,61,545-558.

CROVITZ, H. F., \& ZENER, K. A. A group test for assessing hand and eye dominance. American Journal of Psychology, 1962, 75, 271-276.

GHENT. L. Development changes in tactual thresholds on dominant and non-dominant sides. Journal of Comparative \& Physiological Psychology. $1961,54,670-673$.

JEEVES, M. A., \& DIXON, N. F. Hemisphere differences in response rates to visual stimuli. Psychonomic Science, $1970,20,249-251$.

KIMURA, D. Functional asymmetry of the brain in dichotic listening. Cortex, III, $1967,2,163-178$.

TAYLOR, L. B. Perception of digits presented to right and left ears in children with reading difficulties. Paper presented to Canadian Psychological Association, Hamilton, Canada, 1962. 